\title{
VALIDATION OF THE COMPREHENSIVENESS OF AN INSTRUMENT ON ETHICAL PROBLEMS IN PRIMARY CARE
}

\author{
José Roque JUNGES ${ }^{a}$, Elma Lourdes Campos Pavone Zóbolib, Rafaela SCHAEFER ${ }^{\text {c }}$, \\ Carlise Rigon Dalla NORA' ${ }^{\mathrm{c}}$, Mikaela BASSO ${ }^{\mathrm{d}}$
}

\begin{abstract}
The study aimed to validate the comprehensiveness of an instrument on the occurrence of ethical problems in primary health care and discuss their results. This is a methodological research. The technique used was Delphi, which seeks to obtain a consensus on a subject by experts, using structured questionnaires that are modified to obtain consensus on the comprehensibility of content. The sample was composed by nine professionals with expertise in primary health care in São Leopoldo. Data collection was in March and April 2011 . In the first round, the professional was asked to respond whether the described situation has represented an ethical problem, whether the statement was clear and whether there was any suggestion to rewriting the problem. Were presented thirtysix statements, and to twenty was suggested new rewrite. After the review and systematization the proposed amendments, has begun the second round to seek consensus among all the statements that its writing had changed. In the second round, the consensus required by the method was obtained. Using the method supported significantly to build the instrument in its initial stage, what makes it appropriated and comprehensive for the subsequent steps of the validation.
\end{abstract}

Descriptors: Validation studies. Ethics. Bioethics. Primary health care.

\section{RESUMO}

O estudo teve como objetivo validar a compreensibilidade de um instrumento sobre a ocorrência de problemas éticos na atenção primária à saúde e discutir seus resultados. Trata-se de uma pesquisa metodológica. A técnica utilizada foi a Delphi, que visa obter consenso sobre determinado assunto através de especialistas da área, com questionários estruturados que vão sendo modificados até que se obtenha consenso sobre a compreensibilidade de seu conteúdo. O universo empírico constituiu-se de nove profissionais experts em atenção primária no município de São Leopoldo. A coleta de dados ocorreu em março e abril de 2011. Na primeira rodada, o profissional foi convidado a responder se a situação descrita representava um problema ético, se a afirmação estava clara e se havia alguma sugestão de reescrita do problema. Foram apresentados trinta e seis enunciados e, para vinte deles, foi sugerida nova reescrita. Após a reavaliação e sistematização das modificações sugeridas, iniciou-se a segunda rodada, que já obteve o consenso esperado. A utilização da técnica Delphi colaborou significativamente para a etapa inicial de validação do instrumento, chegando-se a enunciados compreensíveis e adequados para sua aplicação nas subsequentes etapas.

Descritores: Estudos de validação. Ética. Bioética. Atenção primária à saúde.

Título: Validação da compreensibilidade de um instrumento sobre problemas éticos na atenção primária.

a Professor and Researcher, Postgraduate Program of Community Health, Universidade do Vale do Rio dos Sinos, São Leopoldo, RS, Brazil.

b Professor and Researcher, Nursing School of University of São Paulo, SP, Brazil.

c Nursing. PhD Student at Universidade Católica Portuguesa, Porto, Portugal.

d Psychologist at the Universidade do Vale do Rio dos Sinos, São Leopoldo, RS, Brasil. 


\section{RESUMEN}

El objetivo del estudio fue validar la comprensibilidad de un instrumento sobre el acontecimiento de los problemas éticos en atención primaria de salud y discutir sus resultados. Se trata de una investigación metodológica. La técnica utilizada fue la Delphi, que tiene como objetivo obtener un consenso sobre determinado tema por expertos en la materia, utilizando cuestionarios estructurados que son modificados con el fin de obtener un consenso sobre la comprensibilidad de sus contenidos. El universo empírico estuvo constituido de nueve profesionales expertos en atención primaria en São Leopoldo. La recolección de datos ocurrió en marzo y en abril de 2011. En la primera rueda de la técnica Delphi, el profesional ha sido invitado a responder si la situación descrita representaba un problema ético, si la afirmación estaba clara y si había alguna sugerencia de nueva escrita del problema. Han sido presentados treinta y seis enunciados y para veinte hubo sugerencia de nueva escrita. Después de la evaluación y sistematización de las modificaciones sugeridas, ha sido iniciada la segunda rueda que luego obtuvo el consenso esperado. La utilización de la técnica Delphi ha colaborado significativamente para la etapa inicial de validación del instrumento, haciendo posible el uso de enunciados comprensibles y adecuados para las siguientes etapas.

Descriptores: Estudios de validación. Ética. Bioética. Atención primaria de salud.

Título: Validación de la comprensibilidad de un instrumento sobre problemas éticos en la atención primaria.

\section{INTRODUCTION}

The implementation of the Brazilian Health System (called SUS) represented an important step forward for primary health care (APS) especially after the implementation of the Family Heath Strategy (ESF) and consolidation of the National Humanization Policy (PNH). This new health sector configuration aimed to increase the level of co responsibility at different levels of the SUS system to better the quality of its services ${ }^{(1)}$.

With the objective of offering continuous assessment of health quality management, especially for this particular model, the Health Ministry developed the Better Access to Basic Care Quality Program (PMAQ) $)^{(2)}$. Amongst the strategies to improve the health services are the means to self assess oneself which can help in the process of perception and reflection on the ethical problems in the APS. With this, it is hoped that professionals are better able to resolve everyday situations, identifying ethical issues and dealing with them by anticipating, recognizing and resolving these conflicts $^{(3)}$.

Ethical Issues which permeate primary care work are difficult to identify ${ }^{(4)}$. A scenario lacking situations where there is a sense of urgency in making decisions makes questions about ethical issues less evident. Therefore, a tool that allows the professional to identify ethical situations that surface in our everyday life could be important in assessing the work processes in the search for quality of actions taken in health care.

Ethical issues can be understood as challenges which must be acted upon and a better way to re- solve them must be considered on and constantly reassessed ${ }^{(5)}$. They cannot be resolved with a standard formula, but must have a permanently creative approach so the results can be long term, reaching beyond a solution for an individual $\operatorname{case}^{(6)}$.

The tool, proposed in this study, comes from the results of research which clearly showed the ethical problems recognized by nurses and doctors of the ESF in a district in São Paulo ${ }^{(7)}$, and its following systematization in a second research ${ }^{(8)}$, which used the Delphi technique to build up a self applied tool with 3 scopes of ethical problems: between users and professionals, between the professional team and between professionals and the health system. In order to verify how comprehensible this tool was in another practical context, it was decided to let it undergo an evaluation with experts in this field, using the Delphi technique ${ }^{(9)}$. This technique seeks a consensus in areas of understanding still very little explored or consolidated. The effectiveness of the panel occurs from the questioning directed to the experts and the evaluation of their answers on a cumulative basis, with views to maximum consensus ${ }^{(9)}$.

This tool seeks to contribute in the identification of ethical issues of primary health care professionals, encouraging a discussion to find ways to solutions so improving the quality of assistance. Furthermore, its validation will allow these professionals to use this tool in their work.

The objective of this study was to validate the comprehensibility of a tool over the occurrence of ethical problems in primary health care and to discuss its results using the Delphi technique. 


\section{METHODOLOGY}

Proceeding with the construction process and validation of the tool, it was necessary to test the comprehensibility of statements of ethical problems in order that analysis could be made in relation to its apparent validation by the use of the Delphi technique. This test was carried out with the experts of São Leopoldo's primary health care, in the city of Porto Alegre, RS. Until then, the comprehension of statements had been tested in São Paulo ${ }^{(8)}$ and Porto, Portugal ${ }^{(10)}$.

This study is a methodological research. It used the Delphi technique - a structured process using questionnaires to collect information, constantly updating this process until a group consensus is reached ${ }^{(9)}$. The stages of the Delphi technique consist in sending a questionnaire on the proposed theme to each member individually. Followed by the collection of the answers and the analysis by the researcher who compiles a list with all the answers and sends them back to the members of the group. At this stage the specialists are requested to reconsider the list and to answer by indicating if they agree or not with the items. Again the replies are collected once more and the process is repeated until a consensus is reached ${ }^{(9)}$.

The collection of information took place in March and April of 2011. The sample was for convenience, the Health District Office of São Leopoldo (RS) indicated 12 professionals with experience in APS. Nine out twelve agreed to take part in the study. The inclusion criteria were: having experience on the subject studied, working in primary health care for more than a year and having higher education qualifications. The exclusion criteria were: not having any experience on the subject studied, working in primary health care for less than a year and not having a higher education.

The expert panel was formed by 5 doctors, 3 nurses and 1 dentist. Two of them were men and seven women. Their average age was 40 years old. Seven of them specialized in family health, one of them had a doctorate in Medical Science and another didn't have a post-graduate. The average period of time studying and working in primary health care was 13 years.

The professionals answered two rounds of the questionnaire anonymously, aiming for a consensus set at $51 \%$, although this figure could change ac- cording to different authors ${ }^{(9)}$. The tool was sent to the professionals by e-mail and in some cases where there was no response the members were contacted personally. In the first round, there were 38 ethical problems presented to the professionals ${ }^{(8)}$, trying to identify: if the situation described was considered an ethical issue, if the wording was clear and, if not, they were requested to re word the question so it would be clearer. After the first round the results were coded and evaluated adding new wording to the ethical problems where necessary, as suggested.

In the second Delphi round, a questionnaire containing new and old wording were sent out to the experts, with the objective of obtaining the desired consensus ${ }^{(9)}$. In this study a consensus was reached in the second round - this was possible because the questionnaire had been validated in São Paulo $^{(8)}$. For the entry of data EpiData software version 3.1 was used and for analysis the software SPSS (Statistical Package for the Social Sciences) version 12.0, seeking common re-occurrences through descriptive statistics.

This study was approved by the Ethics Committee from the Hospital Conceição Research Group, protocol number 09-156. And all the participants signed a free and clear consent form.

\section{RESULTS AND DISCUSSION}

The attempt to put together a tool to identify ethical issues experienced by professionals in their daily lives has taken many years of research. The purpose of it is to be a motivator in the working process and to humanize health care and give a better quality of assistance.

Table 1 shows the ethical problems which had alterations added by the tool, indicating which ones had their wording altered by the specialist panel. The first column shows the wording proposed by the study made in São Paulo ${ }^{(8)}$, and which was sent to the experts in the first round. The second column shows the suggestions proposed by the panel - the first line indicating the original term used and on the second line the suggestions proposed by the professionals with respective consensus rates obtained by both Delphi rounds. And the last column shows the final version of the ethical problem, after consensus modifications were added.

All the unchanged statements were kept as the original because it was the consensus of the 


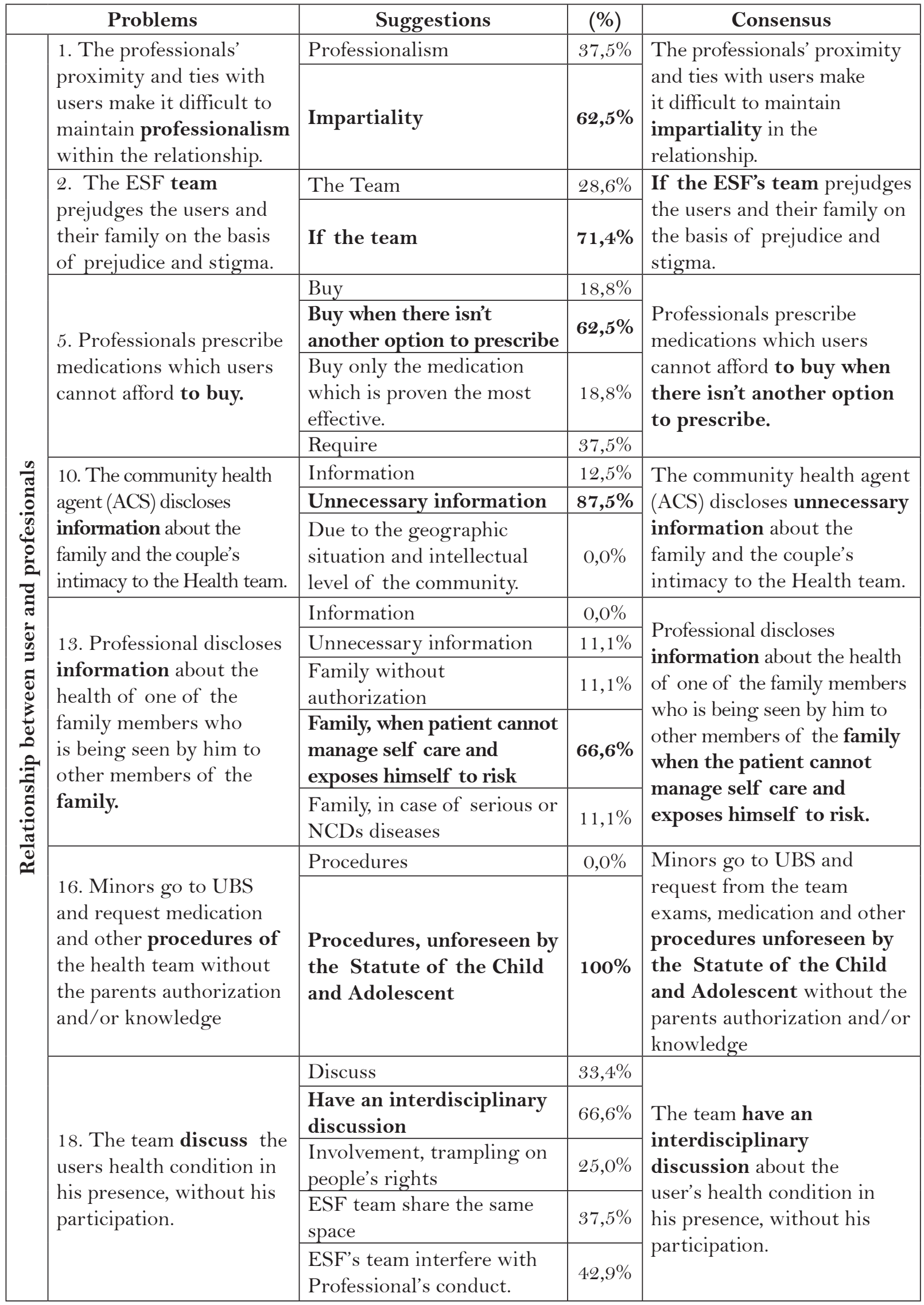




\begin{tabular}{|c|c|c|c|c|}
\hline \multirow{8}{*}{ 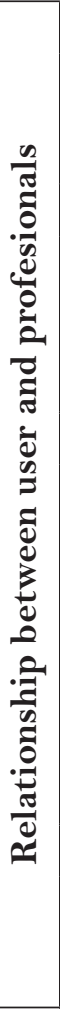 } & \multirow{2}{*}{$\begin{array}{l}\text { 22. The team's } \\
\text { professionals are } \\
\text { unprepared to work at } \\
\text { ESF. }\end{array}$} & Unprepared & $12,5 \%$ & \multirow{2}{*}{$\begin{array}{l}\text { The team's professionals } \\
\text { don't have the ideal profile } \\
\text { to work at ESF. }\end{array}$} \\
\hline & & $\begin{array}{l}\text { Don't have the ideal } \\
\text { profile }\end{array}$ & $87,5 \%$ & \\
\hline & \multirow{2}{*}{$\begin{array}{l}\text { 23. It is difficult to define } \\
\text { in practice and on paper } \\
\text { all the responsibilities } \\
\text { shared by each family } \\
\text { health team Professional. }\end{array}$} & Define & $12,5 \%$ & \multirow{2}{*}{$\begin{array}{l}\text { It is difficult to fulfill, in } \\
\text { practice and on paper, all } \\
\text { the responsibilities shared } \\
\text { by each family health team } \\
\text { Professional. }\end{array}$} \\
\hline & & To fulfil & $87,5 \%$ & \\
\hline & \multirow[b]{2}{*}{$\begin{array}{l}\text { 25. Users request from } \\
\text { one of the family health } \\
\text { team members that } \\
\text { other members don't } \\
\text { have access to some } \\
\text { information related to } \\
\text { their health. }\end{array}$} & To their health & $14,3 \%$ & \multirow[b]{2}{*}{$\begin{array}{l}\text { Users request from one } \\
\text { of the family health } \\
\text { team members that other } \\
\text { members don't have access } \\
\text { to some information } \\
\text { related to their health even } \\
\text { though in some cases it is } \\
\text { necessary that the family } \\
\text { takes part in their care. }\end{array}$} \\
\hline & & $\begin{array}{l}\text { To their health even } \\
\text { though in some cases it's } \\
\text { necessary that the family } \\
\text { takes part in their care. }\end{array}$ & $85,7 \%$ & \\
\hline & 26. UBS Employees & Pres & $0,0 \%$ & \multirow{2}{*}{$\begin{array}{l}\text { UBS Employees raise doubts } \\
\text { about the Professional } \\
\text { conduct of an ESF team's } \\
\text { doctor. }\end{array}$} \\
\hline & $\begin{array}{l}\text { raise doubts about the } \\
\text { prescription of an ESF } \\
\text { team's doctor. }\end{array}$ & Professional conduct. & $100 \%$ & \\
\hline \multirow{7}{*}{ 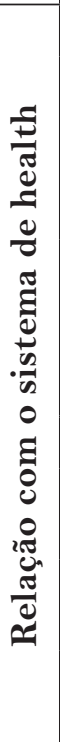 } & \multirow{3}{*}{$\begin{array}{l}\text { 28. ESF team } \\
\text { professionals feel a lack } \\
\text { of support of inter } \\
\text { sector actions to discuss } \\
\text { and resolve ethical } \\
\text { problems encountered in } \\
\text { the work place. }\end{array}$} & Inter-secto & $37,5 \%$ & \multirow{3}{*}{$\begin{array}{l}\text { ESF team professionals } \\
\text { feel a lack of support of } \\
\text { inter sector actions which } \\
\text { depend on organization } \\
\text { and management of the } \\
\text { system, to discuss and } \\
\text { resolve ethical problems } \\
\text { encountered in the work } \\
\text { place. }\end{array}$} \\
\hline & & $\begin{array}{l}\text { Inter sector actions which } \\
\text { depend on organization } \\
\text { and management of the } \\
\text { system. }\end{array}$ & $62,5 \%$ & \\
\hline & & $\begin{array}{l}\text { Professionals, when they } \\
\text { affect the whole group. }\end{array}$ & $37,5 \%$ & \\
\hline & \multirow{4}{*}{$\begin{array}{l}\text { 31. ESF' doctor } \\
\text { refuses to see users that } \\
\text { don't have a medical } \\
\text { appointment for that } \\
\text { particular day, as a result } \\
\text { they limit the access of } \\
\text { users to the UBS. }\end{array}$} & UBS & $11,4 \%$ & \multirow{4}{*}{$\begin{array}{l}\text { ESF' doctor refuses to see } \\
\text { users that don't have a } \\
\text { medical appointment for that } \\
\text { particular day, as a result } \\
\text { they limit the access of users } \\
\text { to the UBS but they are } \\
\text { always taken in. }\end{array}$} \\
\hline & & $\begin{array}{l}\text { To UBS, not emergency } \\
\text { cases }\end{array}$ & $34,3 \%$ & \\
\hline & & $\begin{array}{l}\text { To UBS, but they are } \\
\text { always taken in. }\end{array}$ & $57,1 \%$ & \\
\hline & & Don't accept & $42,9 \%$ & \\
\hline
\end{tabular}

Table 1 - Delphi Rounds - Primary care ethical problems which were altered. Rio Grande do Sul, 20012.

Source: Research data.

specialists that they were clear and comprehensive since they started in the first round (Table 2). So, therefore, we will not focus on these problems but on the ones which were re-written.

The altered ethical problems suggested by the experts in the questionnaire are shown on Table 1.
In general, the suggestions showed that the original terms are often replaced by another more emphatic term. For example: problem 7 "request" for "require" and problem 36 - "don't offer" for "don't accept".It was highlighted that there was no consensus on problem 11. It was 


\section{Ethical Problems}

3. Professional treats the user disrespectfully.

4. Professionals write inadequate or incorrect prescriptions.

6. Professionals prescribe expensive medication although they have the same effect as a cheaper one.

7. User requests exams, medication or other inadequate or unnecessary procedures during a doctor or nurses appointment.

8. Professionals feel powerless to persuade a user to continue with a treatment.

9. Professionals request diagnostic exams without informing the user what is being requested and why.

11. It is difficult to keep user privacy during house calls due to other family members and neighbours interference

12. ACS discloses to neighbors information obtained during its work regarding users and their families.

14. Professionals fail to identify how far they can interfere with the habits or routines of the family or the user with a view to them having a healthier life style.

15. Users refuse treatment because they believe in a divine cure.

17. Users refuse to follow the medical instructions or undergo exams.

19. ESF Professionals' team lack commitment and involvement in their work.

20. The ESF' teams don't collaborate with one another

21. There is a lack of respect among member of the ESF' team members.

24. Professionals fail when faced by an inadequate or wrong prescription.

27. UBS has structural and routine problems which fail to keep the user's privacy.

29. The direction of the USB doesn't act with transparency when sorting out problems with professionals.

30. There are an excessive number of families allocated to each ESF' team.

32. Private health service professionals disregard the diagnostics conducted or therapy done by the family health team doctors.

33. Professionals from other levels of public health care disregard diagnostics conducted or therapy prescribed by the family health team doctors.

34. There are difficulties in the reference and counter-reference system for the realization of complementary exams.

35. There are concerns with the return of lab exams and the reliability of their results.

36. UBS doesn't offer family health teams the conditions to support house calls.

37. UBS doesn't have the conditions to carry out emergency calls.

38. There are no security personnel to remove people from UBS.

Table 2 - Unchanged Ethical issues

Source: Research data

suggested to replace the addition "Due to other members of the family and neighbors interference" for "Due to the geographic situation and intellectual level of the community". The suggestion didn't reach a consensus, because it didn't express the relation with privacy, and so it changed the meaning of it. So, although a change in the wording was suggested, the original meaning was kept.

It was also highlighted that there were suggestions for additional justifications in some problems, but there was no consensus. Problem 19 - the word "involvement", has a positive meaning and it complements the word "compromise", however, when used in the context of "involvement trampling on people's rights" it takes on a negative meaning. When used in the context of professionals involved in improving the quality of assistance, the PNH (National Humanization Policy) refers to the entire clinic, seeking to build up open dialogues taking into consideration the needs, experience and wishes of the user. Only by taking these views will 
it be possible to build a process of co-responsibility between professional and user ${ }^{(11)}$.

Problem 20 - it was suggested to specify "ESF team share the same space". It is implied that the teams which don't share the same space don't need to collaborate between themselves, limiting their relationship with the team. Problem 21 - it was suggested to combine the expression "a lack of respect among members of the ESF team" with "that interferes with the conduct of the professionals". Problem 29 - it was suggested to emphasize transparency in the management of UBS, "when this affects the whole group", in the resolution of problems. To summarize, additions and modifications which altered the meaning of the original statement and restricted very particular cases were not accepted.

Problems 1, 22, 23 and 26-A consensus were reached and the changes suggested by the experts better expressed the issue in question, without altering the meaning. Problem 1 - the word "professionalism" was changed to "impartiality", conveying precisely the limits of a clinical relationship. According to one of the principals of bioethics, justice, it is important to respect with impartiality the rights of each individual ${ }^{(12)}$.

Problem 22 - the word "unprepared" was replaced by "don't have the ideal profile", fits with what is used in everyday working practice. The model and APS configuration require a professional profile which can address not only acute conditions but chronic ones also when promoting and maintaining health ${ }^{(13)}$. One study ${ }^{(6)}$ describes that the lack of qualified professionals with the right profile working in primary health care is due to the fact that the universities still base their teaching on a biomedical model which creates a fragmented perspective of the health-illness process and directs care towards a more curative approach rather than a preventive one ${ }^{(6)}$. According to the authors ${ }^{(1)}$, the changes in the demographics and epidemiological characteristics of the Brazilian population, requires a change from a "hospital centered" model, focusing on acute events, to a model based on health promotion and integration of health services.

Problems 23 and 26 respectively substitute the word "define" with "fulfill" and "prescription" with "conduct". Replacing technical expressions for words with a more ethical connotation helps to improve the understanding of ethical problem. As to the role and responsibilities of the profes- sionals, authors ${ }^{(14)}$ show that the ESF team work has taken on a new dimension in terms of how the responsibilities for care are divided between the team members.

In problems 10 and 18 respectively, the word "unnecessary" was combined with the word "information" and the word "inter-disciplinary" with the word "discussion". There was a consensus on these additions and they also provide greater definition to the moral connotation of the wording. The right to privacy and confidentiality of information is one of the user core rights which should be ensured in a project of humanization. When you work in a team, information exchange is paramount to provide quality assistance to the individual; however it must be limited to that which is necessary for each member of the team to carry out their activities to the benefit of the user. Ethical conduct is also required from the professionals involved ${ }^{(15)}$.

In primary health care, information about the intimacy of the users and their families are often undermined due to a poor structural layout of services, procedures and unit routine, which can also compromise the privacy of the user ${ }^{(16)}$.

In problems 2 and 13, the additions changed the wording category into a conditional, that is to say, they were added to the circumstances so they could describe ethical problems. In problem 2 at the beginning was added the word "If". According to the study ${ }^{(1)}$, the National Humanization Policy seeks to reinforce the user's rights by reducing the cases of discrimination. But it is still necessary to improve and create new policies to ensure quality of assistance, security and to secure the users rights in the health service.

In problem 13 - the family was told conditionally about the user's health "when the patient cannot manage self care and exposes himself to risk". In this sense, the word "when" functions as a condition for breaching of secrecy. It is considered secret not only the information revealed in confidence but everything that the team sees during their working activities. It is the team's duty to keep confidentiality and is an ethical obligation of the professional ${ }^{(15)}$.

Problems 25 and 28 generate doubts in the understanding of the wording. In problem 25 , the experts understood that the "other members" was referring to the family, but it was originally the members of the team. In problem 28, the term 
"intersector actions" was complemented by "which depend on the organization and management of the system". In problem 28, it isn't clear whether the intersector actions refers to the health care network or also to other sectors outside the health system. The addition suggested didn't clarify this doubt and also raised the question of the possibility of having inter sector actions independent of the organization and management.

It is worth pointing out the importance of services to create initiatives to support professionals in solving ethical problems and so helping them to develop ethical competence. The educational process is a mediating tool for this and can help professionals to develop the tools and abilities necessary to resolve ethical problems encountered day to day in the work place ${ }^{(17)}$.

In problems 5, 13 and 25-the additions made to the original version were changed into a new wording with modified meanings. In problem 5 , the wording "professionals prescribe medications which users cannot afford" was complemented by "when there isn't another option to prescribe". In problem 13, "professional discloses information about the health of one of the family members who is being seen by him to other members of the same family" was complemented with the expression "when patient cannot manage self care and exposes himself to risk". In problem 25 it was suggested that" users request from one of the family health team members that other members don't have access to some information related to their health." could be complemented with "even though in some cases it is necessary that the family takes part in their care". The researchers considered that these statements could change the original meaning of the problems and it was agreed that the wording should be rewritten on the final version as new ethical problems - without excluding the original ones.

In reference to confidentiality of information, one research ${ }^{(18)}$ done with medical students, showed that they had concerns about maintaining the confidentiality of the medical records of the patients and of deciding when was the best moment to share it with the team, particularly with the health community worker, who might even be the patient's neighbor.

The contributions to problems 16 and 31 reached a consensus, but they were not accepted by the researchers for the tool's final version, because they were not compatible with the understanding of ethics adopted in the study. Problem 16 talks about procedures requested by a minor without the parent's authorization, after "procedures" was added, "procedures unforeseen by the Statute of the Child and Adolescent". This addition can express a judicial fallacy of bioethics which reduces the moral concern to a legal one ${ }^{(19)}$. In these cases professionals try to wash their hands of the problem experienced, stating as a reason, the legislation. It highlights the need for the professional to be co responsible with the user and provide humane and quality assistance.

In problem 31, the addition of "But they are always taken in" was suggested. This modification wasn't kept because the researchers understood that the addition expressed a removal of professional responsibility and not an ethical commitment ${ }^{(20)}$, based as it was, simply, on good intentions.

\section{FINAL CONSIDERATIONS}

The tool, after the Delphi rounds, combined a total of 41 ethical problems. The use of the Delphi technique in the process of validating a tool to assess the ethical problems in APS, helped in the understanding and writing of the ethical statements.

One limitation of this study could be the fact that validation of the comprehensibility was made by highly qualified professionals - namely doctors and nurses, however it has been proposed that later on it will be used by all of the health team including professionals with a lower level of qualification. However we consider that the process of comprehensibility could be related more to the context of primary health care than the academic level of the professionals.

The application of the Delphi technique allows us to analyze, in a systematic way, the opinions of experts validating the contents of the tool, and therefore to better improve its comprehensibility. The test of comprehensibility proposed by the Delphi technique is an essential step in validating an assessment tool for ethical problems occurring in the APS; since it can qualify medical care within the services, raise the consciousness of professionals about these problems, allowing for well balanced meetings, discussions and actions in the team. This validation will contribute to the next stage of the research, which consists of testing the validity of the construct and the internal consistence of the 
inventory of ethical problems, with the goal of its possible use in quantitative studies.

\section{REFERENCES}

1 Paim J, Travassos C, Almeida C, Bahia L, Macinko J. O Sistema de saúde brasileiro: história, avanços e desafios. The Lancet [Internet] 2011 May:11-31 . DOI: 10.1016/So 140-6736(11)60054-8. Available in: http://download.thelancet.com/flatcontentassets/ $\mathrm{pdfs} / \mathrm{brazil} / \mathrm{brazilpor}$ 1.pdf

2 Ministério da Saúde (BR). Programa Nacional de Melhoria do Acesso e da Qualidade da Atenção Básica (PMAQ). Brasília (DF); 2011.

3 Zoboli E, Soares F. Capacitação em bioética para profissionais da saúde da família do município de Santo André, SP. Rev Esc Enferm USP. 2012;46(15):1248-53.

4. Laabs CA. Primary care nurse practitioners' integrity when faced with moral conflict. Nurs Ethics. 2007;14(6):795-809.

5 Gracia D. Ethical case deliberation and decision making. Med Health Care Philos. 2003;6(3):227-33.

6 Junges JR, Schaefer R, Della Nora CR, Basso M, Silocchi C, Souza MC, et al. Hermenêutica dos problemas éticos percebidos por profissionais da atenção básica. Rev Bioét. 2012;20(1):97-105.

7 Zoboli ELCP, Fortes PAC. Bioética e atenção básica: um perfil dos problemas éticos vividos por enfermeiros e médicos do Programa Saúde da Família, São Paulo, Brasil. Cad. Saúde Pública. 2004;20(6):1690-9.

8 Silva LT. Construção e validação de um instrumento para mensuração de ocorrência de problema ético na atenção básica [dissertação]. São Paulo (SP): Escola de Enfermagem da Universidade de São Paulo; 2008.

9 Keeney S, Hasson F, Mckenna H. Consulting the oracle: ten lessons using the Delphi technique in nursing research. J Adv Nurs. 2006;53(2):205-12.

\section{Author's address / Endereço do autor / Dirección del autor}

José Roque Junges

Caixa Postal 101, UNISINOS

9300 1-970, São Leopoldo, RS

E-mail: roquejunges@hotmail.com
10 Amado, JDN. Avaliação de ocorrência de problemas éticos em cuidados de saúde primários [dissertação]. Porto: Universidade Católica Portuguesa, 2010.

11 Pasche DF, Passos E, Hennington EA. Cinco anos da Política Nacional de Humanização: trajetória de uma política pública. Ciênc Saúde Colet. 201 1;16(11):4541-8.

12 Junqueira CR. Bioética: conceito, fundamentação e princípios. São Paulo: Universidade Federal de São Paulo; 2011. Available in: http://www.unasus.unifesp.br/ biblioteca_virtual/esf/1/modulo_bioetica/Aula01.pdf

13 Mendes EV. O cuidado das condições crônicas na atenção primária à saúde: o imperativo da consolidação da estratégia da saúde da família. Brasília (DF): Organização Pan-Americana da Saúde; 2012.

14 Araujo MBS, Rocha PM. Trabalho em equipe: um desafio para a consolidação da estratégia de saúde da família. Ciênc Saúde Colet. 2007;12(2):455-64.

15 Przenyczka RA, Kalinowsli LC, Lacerda MR, Wall ML. Conflitos éticos da enfermagem na atenção primária à saúde e estratégias de enfrentamento. Ciênc Cuid Saúde. 2011;10(2):330-7.

16 Silva LT, Zoboli ELCP, Borges ALV. Bioética e atenção básica: um estudo exploratório dos problemas éticos vividos por enfermeiros e médicos no PSF. Cogitare Enferm. 2006;11(2):133-42.

17 Grady C, Danis M, Soeken KL, et al. Does ethics education influence the moral action of practicing nurses and social workers? Am J Bioeth. 2008;8(4):4-11.

18 Ferreira RC, Silva RF, Zanolli MB, Varga CRR. Relações éticas na Atenção Básica em Saúde: a vivência dos estudantes de medicina. Ciênc Saúde Colet. 2009;14(Supl 1):1533-40.

19 Garzon Diaz FA. Hechos y valores: ¿falacia o metafalacia? Rev Latinoam Bioét. 2007;7(12):102-9.

20 Brehmer LCF, Verdi M. Acolhimento na Atenção Básica: Reflexões éticas sobre a Atenção à Saúde dos usuários. Ciênc Saúde Colet. 2010;15(Supl 3):3569-78.

Received: 08.05.2013

Approved: 24.02.2014 